AGH DRILLING, OIL, GAS • Vol. $30 \cdot$ No. $1 \cdot 2013$

http://dx.doi.org/10.7494/drill.2013.30.1.145

\author{
B.V. Kopey*, S.I. Galiy**, S. Bednarz***
}

\title{
EFFECT OF CHANGES \\ IN OPERATING POWER OF GASMOTOCOMPRESSORS 10 GKN ON THE DIAGNOSTIC SIGNS OF CONNECTING ROD BEARINGS DEFECTS
}

Much of the operational power of booster compressor stations (BCS) in Ukraine belongs to gasmotocompressors (GMC).

At the reduction of natural gas production and a limited number of GMC modifications, operated at different sites of the gas industry, it's necessary periodically to carry out their reconstruction for the best performance of units. On the other hand, the reconstruction of the units is associated with significant cost and complexity of its implementation in operating conditions, and for insurance of reliable work at given regimes the most of gasmotocompressors are run at different values of the effective power of the gas engine.

Existing recommendations for routine preventive maintenance governs the conducting repairs of machines, running on different operating regimes, with the same frequency [1]. But as the experience of many objects of SC "Ukrgasproduction" shows, the use of this recommendation is not always justified. Hence, the current situation is the revision of routine preventive maintenance of gasmotocompressors primarily on optimizing of the timing of their implementation.

To improve the operational efficiency of gasmotocompressors the methods that allow receiving of information about the actual state of GMC by developed portable devices for vibrodiagnostics of connecting rod bearings, cylinder group and turbochargers previously have been implemented [2]. The conducting of periodic technical inspection of GMC using such devices can increase the probability of premature defects. However, the use of periodic diagnostic work is not enough to ensure the maximum reliability of the fleet of GMC at the sites of the gas industry.

* IFNTUOG, Ukraine

** UkrNDIgas, Ukraine

*** AGH University of Science and Technology 
In article [3] the concept of the new system of optimal planning of units repair with integrated forecasting technical condition is described. This system combines the solution of such important technical issues:

- A mathematical model creation based on the dependence of vibration levels on time, power and establishment of acceptable levels of vibration at the frequency bands of GMC with developing of methods for evaluating the technical state by the frequency components of the vibration spectrum.

- Numerical determination of the general level of acceleration by the registration of vibration signals of aggregates basic units to compute the fast Fourier transformation.

- Mathematical modeling: the spectra of vibration, spectra of bypass line, stiffness of bearings, identification of vibrations associated with forced and free oscillation, vibration characteristics change over time.

- Mathematical modeling for identification and prediction of integral normalized technical state GMC based on results received from vibration and thermal tests.

- Practical use of complex models for predicting of GMC maintenance for optimal planning of repairs based on the real state of machine.

However, we believe that this system of optimal planning of units repair should include creating of a model of GMC reliability assemblies considering gasmotocompressors work at different operating power.

In [4] a method of determining of performance of reliability and resource gasmotocompressors MK-8, GMC-10 GK has been proposed. The reliability, uptime probability, failure rate of gasmotocompressors MK-8 and GMC-10 GK was defined. Also a strategy of routine preventive maintenance for compressors has been developed. But in these studies, the optimal strategy of routine preventive maintenance in determining of units reliability the effect of changing of the effective power of the gas engine MK-8, GMC-10 GK has not taken into account and in connection with this the change of load on the engine components.

To determine the optimal strategy of the frequency of repairs including work of gasmotocompressors at various operational capacities, as well as carrying out the repairs when reviewing the position of routine preventive maintenance of compressors it's necessary to create the appropriate techniques of reliability calculation, determination of the probability of failure of GMC assemblies, determining the intensity of their failure that was the purpose of our study.

The problem was tasked for determining the reliability; determine the probability of failure-free operation, fault intensity of the most important units of the gas engine - connecting rod bearing of crankshaft. The determining of the reliability must be carried on units that are run at different operating regimes with different effective power of the gas engine. Performance analysis will help to determine their dependence on the effective capacity and give the possibility to develop the optimal timing of connecting rod bearings repair for gasmotocompressors $10 \mathrm{GKN}$ that will increase the reliability of operation, reduce the cost of units repair.

To solve this problem the analysis of the data maintenance forms for the period 20032009 on units was realized that run on different operating conditions (Tab. 1). 


\section{Table 1}

Dynamics of the connecting rod bearings to failure of GMC at different effective power

\begin{tabular}{|c|c|c|c|c|}
\hline \multirow[b]{2}{*}{$\begin{array}{l}\text { The range } \\
\text { of work } \\
\text { to failure, } \\
\text { hours }\end{array}$} & \multicolumn{4}{|c|}{ Number of connecting rod bearings defects } \\
\hline & $\begin{array}{c}\text { Chervono- } \\
\text { donetska BCS } \\
\text { (Effective power } \\
950-1000 \mathrm{~kW})\end{array}$ & $\begin{array}{c}\text { Tymofiyivska UCP } \\
\text { (1 stage) } \\
\text { (Effective power } \\
800-850 \mathrm{~kW})\end{array}$ & $\begin{array}{c}\text { Tymofiyivska UCP } \\
\text { (2 stage) } \\
\text { (Effective power } \\
700-730 \mathrm{~kW})\end{array}$ & $\begin{array}{l}\text { Mashevska BCS } \\
\text { (Effective power } \\
600-650 \mathrm{~kW})\end{array}$ \\
\hline 500 & 344 & 134 & 23 & 18 \\
\hline 1000 & 108 & 38 & 8 & 17 \\
\hline 1500 & 44 & 29 & 8 & 10 \\
\hline 2000 & 52 & 17 & 2 & 7 \\
\hline 2500 & 40 & 15 & 5 & 3 \\
\hline 3000 & 32 & 12 & 8 & 6 \\
\hline 3500 & 16 & 10 & 3 & 4 \\
\hline 4000 & 4 & 8 & 4 & 10 \\
\hline 4500 & 16 & 7 & 0 & 0 \\
\hline 5000 & 20 & 4 & 0 & 0 \\
\hline 5500 & 4 & 7 & 2 & 3 \\
\hline 6000 & 0 & 4 & 1 & 1 \\
\hline 6500 & 4 & 3 & 2 & 9 \\
\hline 7000 & 0 & 2 & 0 & 1 \\
\hline 7500 & 4 & 2 & 0 & 1 \\
\hline 8000 & 0 & 1 & 1 & 2 \\
\hline 8500 & 0 & 1 & 0 & 0 \\
\hline 9000 & 0 & 2 & 1 & 1 \\
\hline 9500 & 0 & 1 & 0 & 0 \\
\hline 10000 & 0 & 2 & 0 & 0 \\
\hline 10500 & 0 & 2 & 0 & 0 \\
\hline 11000 & 0 & 2 & 0 & 0 \\
\hline 11500 & 0 & 1 & 0 & 0 \\
\hline $\begin{array}{l}\text { Total number } \\
\text { of defects }\end{array}$ & 688 & 304 & 68 & 95 \\
\hline
\end{tabular}

The frequency of repairs related to the destruction of the connecting rod bearing inserts on gasmotocompressors of Chervono-donetska BCS (effective power gas engines equal to 950-1000 kW), Tymofiyivska unit of cycling process USP (1 stage) (effective power of gas engines on 1 stage equal to $800-850 \mathrm{~kW}$ and $700-730 \mathrm{~kW}$ on 2 stage), Mashevska BCS (effective power gas engines on 1 stage equal to $600-650 \mathrm{~kW}$ ) has been analyzed.

It's necessary to note that according to the provisions of routine preventive maintenance, developed by the manufacturer of GMC, the frequency of inspection is regulated by value of 500 hours. 
Throughout the period of research of work to failure of connecting rod bearings of GMC at different effective power the technical reviews of 15 units for Chervono-donetska BCS, 8 units of Timofiivska UCP stage 1 and 4 units of 2 stage, respectively, as well as 7 units of Mashevska BCS was analyzed.

The results are shown in the table which indicates that a significant number of failures accounted for the first three range of work of the aggregates. What does the table shows that the total number of failures compared to failure values in the first range of work for each of the objects, you can establish a relationship of this comparison of the effective power of gasmotocompressors. Therefore, it is obvious that great attention should be paid to determining the differentiated approach to determine the frequency of inspection.

Using these systematic data the probability of failure of performance for each trial variant were calculated [4]. According to our data we constructed curves of probability of failure of connecting rod bearings (see Fig. 1).

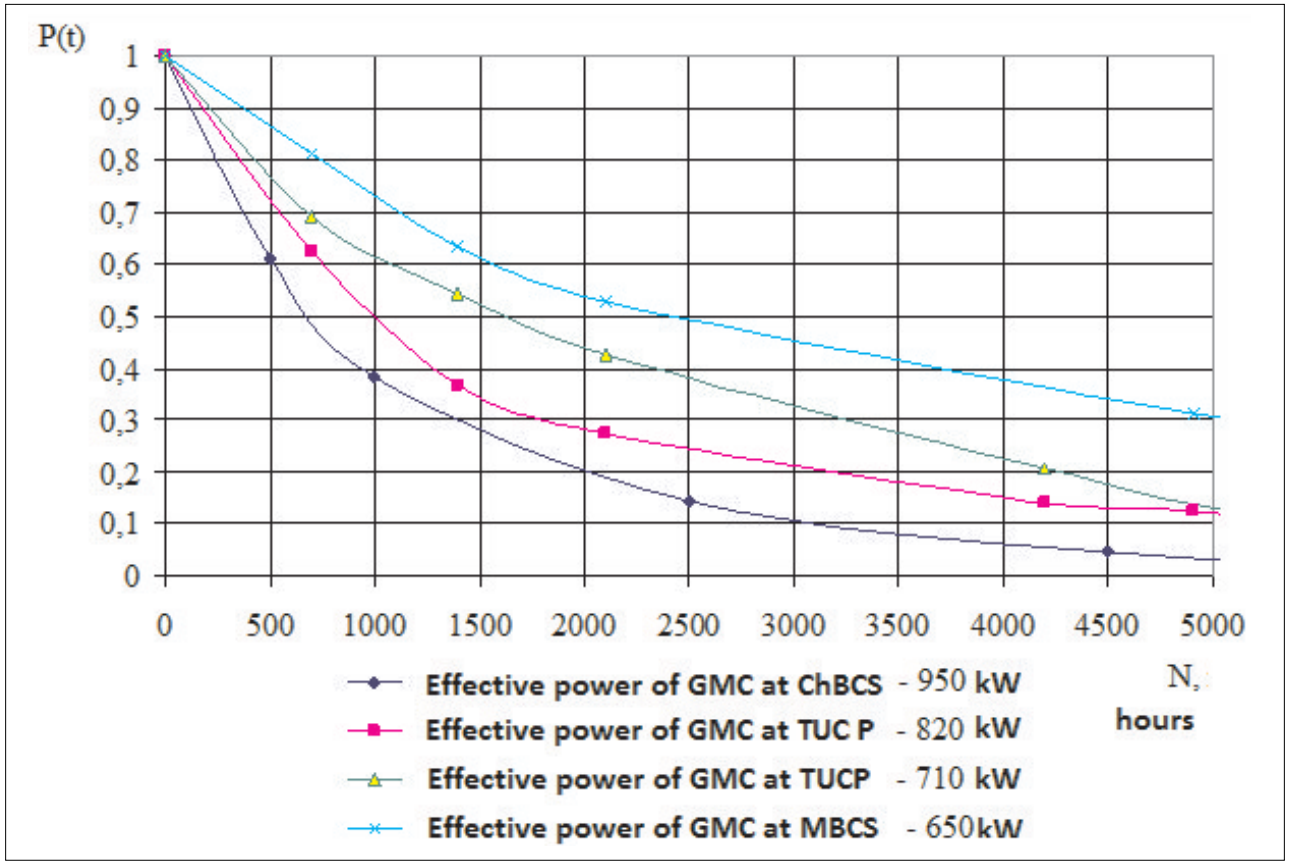

Fig. 1. The probability failure curves of connecting rod bearings for GMC $10 \mathrm{GKN}$

The distribution curves of the probability of failure of connecting rod bearings GMC 10 GKN depending on the effective power of units shows that when using GMC with the value of the effective power $950 \mathrm{~kW}$ (rated power units $1100 \mathrm{~kW}$ ) probability of non-failure is equal to 0.5 . When the inspection is after 500 hours there is a high probability of crankshaft scoring due to the possibility of premature defects of crank bearings. Thus, during the operation of units on the regimes close to nominal, it's necessary to perform the technical inspection of conrod bearing through the intervals of 350 hours. 
Contrary, the probability of failure of connecting rod bearing assemblies, working with engine power equal to $650 \mathrm{~kW}$, while the inspection is realized after 500 hours, is almost 0.9 . Therefore, to increase the duration of the overhaul period, reducing the cost of repairs while ensuring a sufficient probability of failure-free operation we can change the frequency of inspection from 500 to 1000 hours.

Analyzing the Figure 1, we can conclude that the operation of GMC with an effective capacity of $710 \mathrm{~kW}$ and $820 \mathrm{~kW}$ to optimal inspection frequency corresponds the value of 700 hours and 600 hours respectively.

We also calculated the intensity of the fault of the connecting rod bearings [4] and plotted the intensity of failures based on our data (Fig. 2).

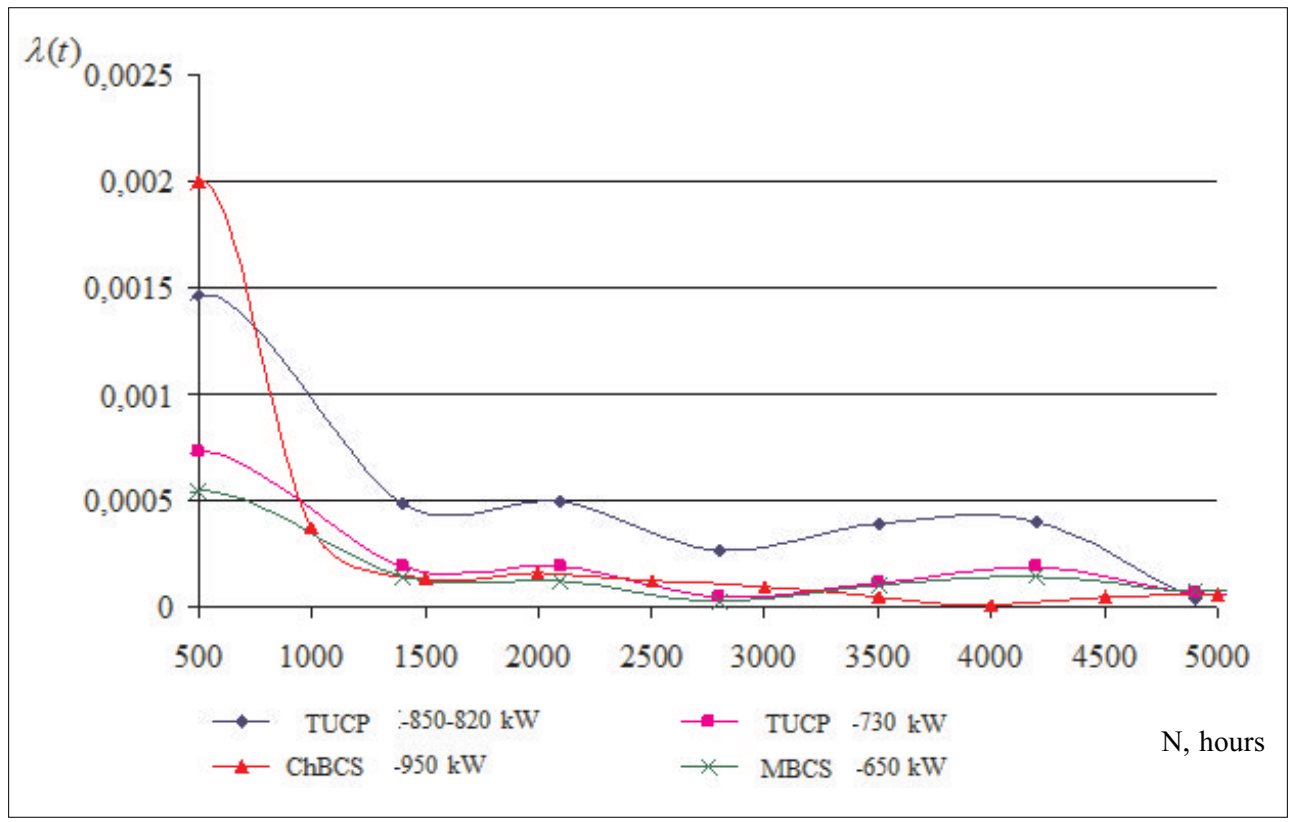

Fig. 2. Graph of failure rate of the connecting rod bearings GMC $10 \mathrm{GKN}$

Analysis of graph shows that the highest failure rate of conrod bearings occurs in the first stage. With efficient power of GMC, close to the nominal values (Chervonodonetska $\mathrm{BCS}, \mathrm{Ne}=950 \mathrm{~kW}$ ), during the first step is the occurrence of $50 \%$ of conrod bearings defects. Operation regimes for units with less power (Mashevska UCP, $\mathrm{Ne}=650 \mathrm{~kW}$ ), can reduce the failure rate to $25 \%$.

Considerable variation in the intensity of conrod bearing failures emphases the need for a differentiated approach to the inspection frequency. This will reduce the chance of crankshafts scoring and operating costs to ensure the highest allowable duration of the aggregates without stopping. 
We suggest to use the method for determining the optimal strategy of the frequency of scheduled repairs including work of gasomotocompressors for different values of the effective power of the gas engine.

WE defined reliability, uptime probability, failure rate of the most important units of the gas engine - crank bearings of gasmotocompressors $10 \mathrm{GKN}$.

Using the figures of probability uptime, failure rate of conrod bearings of GMC we determined the frequency dependence of scheduled repairs for connecting rod bearings that provide sufficient probability of operational capacity of gas engine.

Using the methodology for determining the frequency of routine technical repairs including work of gasmotocompressors for different values of the effective power on the example of connecting rod bearings it allows for a science-based selection of frequency of repairs for all major components of aggregates.

These indicators of repairs frequency for all major components of aggregates will reduce the possibility of random failures, idling of aggregates, prolong turnaround time, reduce the spending for repairs while ensuring a sufficient probability of failure-free operation.

\section{REFERENCES}

[1] Копей Б.В., Бобошко Ю.О., Костів В.В., Міщук Т.В.: Оцінка надійності та вибір стратегї технічного обслуговування газомотокомпресорів МК-8 на основі аналізу $A B C$. Розвідка та розробка нафтових і газових родовищ, 4(21), 2006, 71-75.

[2] Копей Б.В., Бучинський М.Я., Палиця Є.I.: Оиінка надійності та вибір стратегій технічного обслуговування газомотокомпресорів 10 ГК на основі аналізу $A B C$. Розвідка та розробка нафтових і газових родовищ, № 36 (том 3), 1999, 218-222.

[3] Копей Б.В., Копей И.Б. Драгомирецкий Я.Н.: Определение оптимальной величины наработки между отказами деталей нефтепромыслового оборудования. Нефтепромысловое дело, № 10-11, 1997, 30-32.

[4] Підвищення надійності газотранспортних систем: монографія / Б.В. Копей, А. Бенмуна, В.І. Слободян та ін.- Івано-Франківськ: ІФНТУНГ, 2012, 300. 